УАK 342.55

ББK 67.400.7

DOI 10.22394/1682-2358-2018-5-87-91

E.V. Malinenko, Candidate of Sciences (Law), Docent of the Constitutional and Municipal Law Department, South-Russian Institute of Management, Branch of the Russian Presidential Academy of National Economy and Public Administration

\section{CONSTITUTIONS \\ AND CHARTERS \\ OF THE SUBJECTS \\ OF THE RUSSIAN \\ FEDERATION \\ IN MODERN REALITIES}

Constitutions and charters of the subjects of the Russian Federation are considered as integral structural and functional elements of its legal system. Gaps and collisions of these documents are identified. It is noted that the current condition of the Russian state requires constant clarification of legal norms and, accordingly, amending the constitution and charters of the subjects of the Russian Federation.

Key words and word-combinations: constitution, charters, subjects of the federation, constitutional doctrine.
Э.В. Малиненко, кандидат юридиеских наук, дочент кафедри конституционного и муниципального права Южно-Российского института управления - филиала Российской академии народного хозяйства и государственной службъ при Президенте РФ (email: lora.alњ mail.ru)

\section{КОНСТИТУЦИИ И УСТАВЫ СУБЪЕКТОВ РОССИЙСКОЙ ФЕАЕРАЦИИ В СОВРЕМЕННЫХ РЕААИЯХ}

\begin{abstract}
Аннотащия. Рассматриваются конституции и уставы субъектов Российской Федерации как неотъемлемые структурно-функциональные элементы ее правовой системы. Выявляются пробелы и коллизии этих документов. Отмечается, что современное состояние Российского государства требует постоянного уточнения правовых норм и, соответственно, внесения изменений в конституции и уставы субъектов Российской Федерации.

Ключевые слова и словосочетания: конституция, уставы, субъекты федерации, конституционная доктрина.
\end{abstract}

A

ктуальность проблемы российского конституционацизма в региональном измерении усиливается в связи с происходящими изменениями в государстве и обществе. Конституции и уставы субъектов Российской Федерации - неотъемлемые структурно-функциональные элементы ее правовой системы, ставшие предметом научных исследований не в послеАнюю очереАь по причине комиизй, пробелов и противоречивых норм, характерных дмя многих из них. 
Высказанная ранее авторская позищия об особом значении разработки теории разделения полномочий остается значимой и Амя настояшего времени [1, с. 28] . Незавершенность дискуссий по данной проблематике в науке конституционного права предполагает необходимость системного анализа конституџий и уставов субъектов РФ.

Сложившиеся тенденџии в современной юриспруденџии предполагают несколько направлений развития конститущионного правотворчества. В ходе эволюџии российского конститущионализма постепенно утверждается принцип верховенства Конституции России и закона, что и должно определять иерархию источников права. В основе конџептуальной идеи правовой иерархии - построение единой модели конституџий и уставов субъектов РФ, соответствующей нормам Основного Закона РФ. По нашему мнению, в процессе реализации конституџионных принципов российского федерализма следует руководствоваться доминирующим направлением конституџионной практики - распределением публичной власти между федеральным центром и отдемьными составмяющими Федераџию территориями [2, с. 20] .

И.Н. Барџиц отождествляет идею правового единства с совместным, кооперированным выполнением поставленных переА единым федеративным государством задач [3]. Суть позищии Т.Н. Карасевой заключается в необходимости обеспечения правового единства на основе общих принципов российского федерализма, определяющих природу государственного устройства страны [4, с. 28]. Федеративная природа выражается в конституциях и уставах субъектов РФ через правовой анализ статуса субъекта Федерации. Например, статус Ростовской области определяется Конституџией РФ и Уставом области и может быть изменен по их взаимному согласию в соответствии с федеральным конституционным законом [5] . В рамках такого подхода некоторые ученые-правоведы, например К.А. Ишеков, отмечают влияние внешних факторов на тенденџии процесса нормативных предписаний конституџий и уставов субъектов РФ, несовпадение характеристик их правового статуса и многообразие правовых норм [6, c. 2]. Аанный подход сформировался достаточно Аавно, при этом отметим возможность существования иной позищии относительно практики конституционного правоприменения в российских регионах.

Следует отметить необходимость внедрения в политическую практику нового термина «региональная конституционалистика». Процедура реализации нормативных правовых актов основывается в правовом аспекте на их содержании, определении места в региональной конституџионалистике. Наличие специфических правовых норм, отличающихся особенностями, в основе которых территориальная организаџия пубцичной власти, преАставляет основу формирования конституционной (уставной) теории - теории регионального конституционализма. Формирование концепции правового плюрализма, основанной на тезисе о многообразии правовых норм, позволит радикально влиять на общественное положение человека и гражданина в зависимости от постоянного нахождения (офиџиальной государственной регистраџии) на территории субъекта РФ.

Поводом к размышиениям является и идея Е.А. Печкуровой о возмож- 
ности признания конституций и уставов субъектов РФ основными законами ввиду их слабо выраженной учредительной функщии. По ее мнению, Аанная проблема применима ко всем субъектам РФ, находящимся в пределах Южного и Северо-Кавказского федеральных округов [7, с. 9-10] .

Согласно позищии, сформулированной Я.А.Зориной, существует возможность рассмотрения основных законов (конституций (уставов) субъектов РФ) в качестве формы выражения их политико-правовых статусов: «Из нормативного содержания частей 1 и 2 статьи 66 Конституции Российской ФеАерации следует, что основным предназначением конституции (устава) субъекта Федераџии явцяется придание юридической формы фактическому статусу респубмик, краев, областей, городов федерального значения, автономной области и автономных округов в составе России» [8] .

В соответствии со сложившимися политико-правовыми реалиями назрела необходимость переосмыслить значение конституџий и уставов субъектов РФ в условиях современной государственности и рассмотреть необходимость проведения конституционализации российского права и законодательства. ПроисхоАящие изменения состояния гражданского общества обусловливают сощиальную потребность в постоянном динамичном совершенствовании конституџий (уставов) российских регионов.

Понятие «региональная конституционацистика» Аостаточно ново Аһя конституционного права, но на равне с иными современными юридическими терминами и категориями оно потенџиацьно пригодно к инкорпораџии в категорию актуацьных элементов права, составцяющих его систему. Аанный термин отождествяяет необходимость обозначения понятия на регионацьном уровне и принадлежность к региональной отрасли конституционного права, а не к российскому праву в целом. Обновление конститущионного права с позиций правоприменения делает необходимым научное обоснование и осмысление проблем региональной конститущионалистики, в основе которой - соответствующая конституционная (уставная) теория. В ее контексте правомерно рассмотрение значимости конституций и уставов субъектов РФ в качестве источников конституционного права, что определяет правовое содержание нормативных актов не федерального уровня, связанное с характеристиками, структурой и содержанием конституций и уставов субъектов РФ.

Конституция России обладает фактором юридической стабильности на основе законности и обоснованности. В свою очереАь, конституции республик можно рассматривать в качестве гаранта правовой стабицьности в субъектах РФ. Отсутствие концепции конституционной (уставной) теории преАполагает наличие различных политико-правовых идей, выраженных в нормах конституционного законодательства.

Неурегулированность соотношения юридических понятий «республика» и «государство»и возникновение еАиного правового понятия «госуАарствореспублика»противоречит конституциям республик. Отсутствие правовой концепции их суверенной государственности в составе Российской Федерации приводит к юридическим комиизиям. Аинамика совершенствования 
конституций, законодательное обеспечение необходимости конституционно-правового регулирования отсутствует. Необходимо правовое единство в реализации данного понятия. Равноправие субъектов РФ, выражающееся в их конституционно-правовом статусе, преАполагает приведение конституций республик в соответствие прежде всего применительно использования понятия «государство».По мнению А.Н.Артамонова, «современными проблемами законодательного регулирования на уровне субъектов Федерации... явцяются недостаточный анализ региональными органами государственной власти норм федерального законодательства на фоне динамичного изменения последнего, неверное толкование органами власти положений действующего законодательства» [9, с. 2] .

Отсутствие общей конџепџии предполагает возможность интерпретаџии правовых норм. Отдельные республики в своих конституциях провозглашают себя государствами, иные полагают необходимым исключить данный термин. Конституции республик в составе Российской Федераџии размичны по своей структуре и правовому содержанию. Предпосылки их принятия основаны на совокупности многочисленных факторов. К числу основ конституџионно-правового статуса республик в составе Российской Федерации относятся: основы конституционного строя, связанные с правовым статусом мичности и реализацией права народа на самоопределение, формированием наџионально-госуАарственного устройства, созданием этническими общностями наџиональнокультурных автономий; осуществление принципа народного суверенитета в республиках; наличие Основного Закона и государственных языков, утверждение государственных символов; становление специфической системы органов государственной власти республик [1, с. 30].

По утверждению Н.А. Михалевой, «всем региональным основным законам, как и федеральной Конститущии, присущи однотипные черты и юридические свойства. Это: учредительный характер; нормативность; мегитимность; реальность; прямое действие; встроенность в единую правовую систему России; программность; преемственность; стабильность; юридическая база текущего регионального законодательства; наивысшая степень правовой защиты» [10, c. 43]. Тем не менее обилие специальных научных трудов в сфере исследований конституџий республик в составе Российской Федераџии не привело к общей формулировке конџепџии российского конституџионализма. В краях, областях, городах федерального значения, автономных округах и автономной области в отличие от республик законодательным (представительным) органом государственной вмасти субъекта РФ принимается устав. Уставы субъектов РФ во многом сходны, но также обладают спеџификой, обусловленной кумьтурно-историческими, географическими и социально-экономическими особенностями развития регионов. Структура устава субъекта РФ включает обязательные и дополнительные положения. В ней закрепляются правовые статусы высшего Аолжностного Аиџа, высшего законодательного (преАставительного) органа государственной власти, высшего исполнительного органа государственной власти субъекта РФ. Анализ структуры уставов субъектов Российской Федераџии позволяет сделать вывод о необходимости разработки 
модельных проектов теоретических положений, опреАеляющих структуру и основное содержание устава.

Содержание устава, как и содержание конституции субъекта Федерации, составляют обязательные и дополнительные установленные органами госуАарственной власти правовые нормы. Уставы закрепцяют, как правило, общие принципы правового статуса субъектов РФ; обеспечивают соџиацьно-экономическое развитие территории; способствует формированию комплексного законодательного регулирования; устанавцивает систему органов государственной вмасти субъектов РФ, основанную на институтах непосреАственной Аемократии; способствует формированию политического участия граждан в управлении государственными делами. Верховенство устава по отношению к иным региональным актам предполагает его прямое действие на территории субъекта Федерации и особый порядок его принятия. В соответствии с общепризнанным принџипами верховенства права в случае противоречия региональных нормативных актов уставу действуют нормы устава.

Нынешнее состояние Российского государства требует постоянного уточнения правовых норм и, соответственно, внесения изменений в конституџии и уставы субъектов РФ, а в Аальнейшем реализации конституционных (уставных) норм в правоприменительной практике субъектов РФ. Очевидно, что отсутствие официальной государственной конституционной доктрины как на федеральном, так и на региональном уровне вцечет огромное количество неконструктивного разнообразия структуры и содержания текстов конституџий и уставов субъектов Федерации и приводит к наличию пробелов в теории и практике российского конституционализма.

\section{Библиографический список}

1. Малиненко Э.В. Конституции республик Российской Федерации - основные источники права субъектов Российской Федерации (историко-правовой аспект) // Юрист-правоведъ. 2015. № 4(71). C. 5-8.

2. Добрынин Н.М. Насущные задачи развития российской модели федерализма: онтологический дискурс о системных свойствах Федерации // Государство и право. 2017. № 9.

3. Барции И.Н. О единстве государственной власти в Российской Федерации // Законодательство.2001. № 9 .

4. Карасева Т.Н. Пределы соответствия конституций и уставов субъектов Российской Федерации Конституции Российской Федерации: автореф. дис. ... канд. юрид. наук. Пенза, 2013.

5. Устав Ростовской области (от 19 апр. 1996 г;; с изм. и доп.) [Электронный ресурс]. Доступ из СПС «Гарант».

6. Ишеков K.A. Реализация конституций и уставов субъектов Российской Федерации органами государственной власти: конституционно-правовое исследование. Саратов, 2013.

7. Печкурова E.A. Конституции и уставы субъектов Российской Федерации как источники конституционного права (на примере субъектов, находящихся в пределах Южного и СевероКавказского федеральных округов): автореф. дис. ... канд. юрид. наук. Ставрополь, 2010.

8. Зорина Я.А. Конституция (устав) субъекта Российской Федерации как источник конституционного права: автореф. дис. ... канд. юрид. наук. Белгород, 2008.

9. Артамонов А.Н. Создание законов в субъектах Российской Федерации. Ростов н/Д, 2011.

10. Михалева Н.А. Конституции и уставы субъектов Российской Федерации: сравнительноправовое исследование. М., 2010. 